\title{
Diverging Concepts of the Other in Islam: A Comparison between the Original Islamic Perception and Contemporary Muslims' Practice
}

\author{
Mohammad Sha'aban Deyab", Gamal Elgezeery ${ }^{2}$ \\ ${ }^{1}$ Department of Languages and Translation, College of Arts and Humanities \\ Taibah University, KSA \\ Department of English, Faculty of Arts, Minia University, Egypt \\ ${ }^{2}$ Department of Languages and Translation, College of Arts and Humanities \\ Taibah University KSA \\ Affiliations: Taibah University, College of Arts and Humanities, Department of Languages and \\ Translation, KSA; Suez University, Faculty of Arts and Humanities, Egypt \\ Email: elgezeery@gmail.com, Mohamed_shabban@yahoo.com
}

Keywords: Othering; colonialism; Islam; Madinah Charter; exterior othering; domestic othering

\begin{abstract}
During the time of Prophet Muhammad in Madinah, Muslims' understanding of the Concept of the other was strictly similar to the one described in the Holy Quranic verses. The Prophet himself provides an exemplary practice of the Islamic view of the Other in writing a constitution for people of different religions, tribes, races and ethnicities, living in Madinah. Those others who had agreed to that constitution were allowed to worship in their own way and follow their own religious law, and were given a degree of self-government. However, After Prophet Muhammad, Muslims' conceptions of the other greatly changed partly because of political reasons and conflicts among themselves and in most cases, because of the western colonization of many Muslim countries. The purpose of this paper is to deal with the diverging concepts of the other in Islam. It makes close readings of some Quranic verses revealed in the holy cities of Makka and Madinah and finds that the theoretical concept of the other, as represented in the Quran is based upon positive difference among peoples and communities. Then the paper sheds light on two instances of how Prophet Muhammad positively applied this concept, namely, "The Last Sermon and the Madinah Charter." Next, it surveys the manifestations of the concept of otherness in contemporary theory and practice, especially with reference to colonialism. The last section of this paper tries to interpret the radical changes that have turned the Muslim concept of the other from a positive one to a completely negative view of the other. Muslim contemporary othering is a comprehensive process that is divided by the researchers into exterior othering related to non-Muslims and domestic othering related to Muslims among themselves.
\end{abstract}

\section{INTRODUCTION}

After September 11, 2001, a new wave of antagonism against Islam has arisen, and Muslims have been attacked as intolerant and oppressive. Islam, which is originally a religion of tolerance and peace, is now associated with prejudice and violence. Western people have often perceived Islam as a violent and intolerant faith, and they view it "through their own muddled preconceptions."(Armstrong 2002). In addition, Western media keeps portraying Muslims as prejudiced against people of other religions, claiming that Muslims "cannot tolerate cultural diversity in their own countries or even in the host ones. This explains why they fail to act within mainstream American value systems."'(Toss and Diaz 2009).

These stereotypical notions of Muslims are misleading and perturbing to both the west and Muslims themselves, and they result in an apparently intended misunderstanding of Islam and its followers. Karen Armstrong describes this state of misunderstanding and muddled view as an 
outcome "of western fantasy" (2002). It is a product of an act of exaggerative and overgeneralizing imagination. It exaggerates some individual incidents and overgeneralizes them to be applicable to all the members of the religion to which the perpetrators of these incidents belong. This fantasy is harmful to both the fantasizers and the fantasized because it creates negative images in the minds of each group regarding the other and at the same time it is not faithful to reality.

The best method to comprehend the Islamic standpoint about the relation between Muslims and others is to have a view of both the Quran as a holy book and the teachings and actual practices of Prophet Muhammad as a messenger to whom the message of Islam was divinely revealed. The prototype of this religious tolerant theory and practice is present in many Quranic verses and in the actual teachings and conduct of Prophet Muhammad, Mithaq-1-Madinah (Constitution or Charter of Madinah) being a practical example of practicing the Quranic theory and Prophet Muhammad's teachings.

However, the western stereotypical notions of Islam are not spread ex nihilo, as they can have some roots in the reality of contemporary Muslims, a reality which often runs counter to the commands of the Quran and the teachings of Prophet Muhammad. The main argument of this paper is that the change from the positive view of the other at the beginning of Islam into a negative one in modern and contemporary practices is due to the legacy of colonialism and to the political struggles among Muslims. Occupied for a long time by western powers, some Muslim states citizens try to talk back to former western imperialism in its own language regarding the view of the other.

The objective of this paper is to discuss how the concept of the other has changed from its positive associations in the Quran and its applications in the practices of Prophet Muhammad to its negative modern and contemporary associations. Then it will try to interpret the negative changes attached to the concept of otherness in contemporary practices of some Muslims and Muslim groups. This paper is divided into four main sections. The first section deals with the way the other is viewed in the Quran. The second section is devoted to Madinah Charter or Constitution as an example of how Prophet Muhammad sticks to the Quranic concept of otherness and adapts it to the reality of living in Madinah where diverse ethnicities, religions, and groups lived together: urban people, tribal members, Jews, Christians, Muslims, non-believers, and pagans. The third section tackles the concept of the other and the process of othering in modern and contemporary usage in the west. The fourth section deals with contemporary Muslims and their view of otherness which runs counter to the originally historical view of the other as presented in the Quran and Prophet Muhammad's practices discussed in the first and second sections of this paper.

\section{The Concept of the Other in the Quran:}

The relationship between Muslims and others has been long characterized by misunderstanding and lack of knowledge of Islam and its sublime teachings. The relationship of Islam to the other, both in theory and practice, has been intricate and multifaceted. In the course of history, Islam - as a religion and as a religious community - has come into contact with nonMuslims and their cultures in different situations and at different times and places. As Jacques Waardenburg puts it:

Since its inception the Muslim civilization has been in continuous relationship with other cultures and civilizations. It extends from the Atlantic to the Pacific Oceans and through regions which have long been carriers of culture. As a consequence, Muslims have come into contact with many religions. One may think not only of various forms of Christianity and Judaism inside and outside the Middle East but also of Zoroastrianism and Manicheism, Hinduism, and even Buddhism, not to speak of nonliterate religions in many parts of Asia and Africa. (1999, xi).

The relationship of Muslims to others living among them is long and complex. Islam acknowledges that the other exists and has the right to live in peace in an Islamic community. Contrary to the negative conceptions of the other in some contemporary communities, Islam views this other from a positive perspective. First, Islam agrees with the view that the other is different, where it is God's 
design to have different faiths, race, languages and civilizations. Allah SWT states this clearly in the Holy Quran:

If your Lord had pleased, He would have made all people a single community, but they continue to have their differences - except those on whom your Lord has mercy - for He created them to be this way." (11:118-119)

These two verses state that diversity and difference are inherent characteristics of human beings. God has not created a human mold into which each human being is cast. It is part of the holy design that people should entertain and accept their difference from each other because difference can play a greater part in spreading life on earth, as different groups can provide different views that can help strengthen human relations and make life easier for all.

These two Quranic verses differentiate between difference in communities and differences among individuals. It is clearly stated that people are created as belonging to different communities. Starting from "but" in the verses, there is another difference which is condemned. People draw from the first Quranic statement of the difference of communities conclusions that do not logically result from it. They reason that as long as communities are different, people should use this difference as a reason for differentiation and discrimination. The clause "except those on whom your Lord has mercy" refers to those people who recognize in difference a means of coexistence and peacefulness. It is implicit in the two above-cited Quranic verses that the concept of othering has resulted from people's misunderstanding of the holy design. The existence of different communities does not imply superiority or inferiority. Human practice has twisted such concept of difference and made it acquire such evaluative dimensions. It is noteworthy that the Quranic Sura from which these two verses are cited was revealed to Prophet Muhammad while he was still in Makka. This means that it was revealed in an early year in the age of Islam and that the implications of the verses form part of the fundamental message of Islam because the Suras which were revealed in Makka deal with the basics of Islam as a religion.

Having shed some light on these verses which belong to the early phase of the Islamic mission in Makka, the paper will focus on some Quranic verses that were revealed after Prophet Muhammad's migration to Madinah where Muslims were no longer a minority, as they had been in Makka, and where there was much diversity. When Prophet Muhammad was in Makka, he was among his people and relatives whether they adopted Islam or not. However, in Madinah he was far away from his native land and came into daily contact with diverse kinds of people, ethnicities, and religions. This leads us to shed more detailed light on some of the Quranic verses that were revealed in Madinah and that develop the concept of diversity and urge Muslims to accept and adopt the implications of such diversity.

In a Quranic verse revealed to Prophet Muhammad in Madinah, this integral message of diversity and pluralism is emphasized where it is mentioned that God created a world that includes different nations, ethnicities, tribes, and languages. If He had willed, he could have created us as one and the same, but it is His wisdom to create us different in shapes, languages, colors, beliefs, customs and traditions:

To each of you we have given a law and a way and a pattern of life. If God had pleased He could surely have made you one people [professing one faith]. But He wished to try and test you by that which He gave you. So try to excel in good deeds. To Him will you all return in the end, when He will tell you how you differed. (Quran 5:48).

In the light of this Quranic verse, Islam views diversity amongst humankind as a blessing and as something positive; it is a way for Mankind to learn about each other. It is a worldview and a lifestyle that should be adopted by all peoples and nations. It is part of God's will that peoples are created different. This difference is portrayed here as a test to all human beings. God wants to test them whether they could tolerate and entertain this difference or would they regard diversity as an anomaly that could not be tolerated. In this context, diversity is a one of colors, ethnicities, races, and languages, because God highlights in the same verse the fact that diversity must push all kinds of people to compete for excelling one another "in good deeds." In other words, difference is 
intended here to be a motivation that urges people to become better and to accept diversity as the normal state of life on the earth.

According to the Quran, the best way to achieve co-existence among people of different religions and races is to hold a dialogue among the different peoples and cultures in order to serve the universal objectives of human life on earth. On this, God says:

"O Mankind, We created you from a single pair of a male and a female and made you into nations and tribes, so that you may know one another. Verily the most honored of you in the sight of God is he who is the most righteous of you" (Quran 49:13).

It is remarkable that in this verse and the versed that we cited earlier on in this paper, God either addresses human beings as a whole or addresses Prophet Muhammad and then speaks about humanity at large. When he addresses Prophet Muhammad in this context, he sends an emphatic message to Muslims that they are not the only people on the earth: there are others peoples and nations who are different and their difference contributes to serving God's purpose on earth, i.e. diversity and competition for doing good deeds. When God speaks directly about human beings in general, he speaks in his capacity of being the Creator of the world and emphasizes the same message.

In this above mentioned verse, God calls our attention to the fact that all human beings have the same ancestral origin because they have the same father and mother. However, He immediately asserts diversity so that the reader of this Quranic verse might not derive fallacious conclusions from it. Having the same origin does not mean identity or identical correspondence, in the translational sense of the term. The purpose of diversifying people into different nations and tribes is to acquire knowledge of one another. In other peoples, difference and diversity should lead peoples to know one another, culturally, socially, politically, economically, religiously, etc.

We can draw several fundamental Islamic principles regarding the other which are reaffirmed elsewhere in the Quran and the Prophet's teachings. First, the verse emphasizes the fact that Allah addresses all of humanity, not only Muslims, and that all humans are ethnically equal because they all share the same father and mother. Secondly, this verse emphasizes that all humans are equal regardless of race, language, color, and nationality because these things were one and the same, and it is God who later ordered diversity among them. Thirdly, the verse refers to the ultimate goal of creation which is represented in holding dialogues among the different nations and peoples so that they can know one another better. Fourthly, in the same verse, God uses the emphatic "verily" or "inna" in Arabic (with a stress on the "n" sound) to reassert what is frequently asserted elsewhere in the Quran: good acts and deeds are what really distinguishes a people from another, a person from another, regardless of ethnic, racial, national, religious, or social affiliations.

Islam itself orders its followers to protect the freedom of belief and worship for followers of other religions. Allah says in the Quran

For, if God had not enabled people to defend themselves against one another, monasteries, and churches and synagogues and mosques - in which God's name is abundantly extolled would surely have been destroyed. (22: 39-40)

These two Quranic verses were revealed in Madinah as well. They imply that diversity and difference may engender disputes and invasion because peoples or communities, as referred to in a previous quotation from the Quran, may understand difference fallaciously.

In these verses, self-defense is a tool of resisting such attacks and invasions. These verses make self-defense a means of defending and preserving one's religion and sacred worship places. The reference to Christians' churches and the Jews' synagogues before the mosques indicate their significance as places of worships and the duty of Muslims to protect them against any desecration in order to ensure the freedom of belief. This reference also acknowledges the historical precedence of these two religions to Islam. That they historically came before Islam necessitates this syntactic ordering of the worship places devoted to the three religions. Here, the Quran inculcates in the minds of Muslims that there had been other religions preceding Islam and that these religions and their worship places should be respected and honored just as Muslims respect and honor mosques. "It is for this tolerance in the Islamic view that Muslims have looked at the religion of the people in 
the lands they conquered with respect; they did not intervene with their beliefs nor touch their churches" (Can, 2005, 172).

All these Quranic verses, whether they were revealed to Prophet Muhammad when he was in Makka or after he migrated to Madinah, assert difference and diversity as a general rule governing life on earth. It is part of God's design that peoples lead different lives, have different worldviews and religions, and differ from each other in ethnicities, nationalities, races, languages, beliefs, social traditions, etc. However, this difference is to be understood as a means of enriching the diversity that makes all people form a whole represented in humanity. Sustaining this view of difference and diversity is a view of the "other" as only different in degree, not in kind. This difference relates only to superficial human markers such as color, geographical location, ethnic affiliations, languages, religions, etc.

\section{Prophet Muhammad's Application of the Quranic Concept}

Having shed light on the Quran's attitude towards the diversity that encompasses life on earth, the paper will discuss the practices of Prophet Muhammad and show how he turned the theoretical principles and rules of the Quran into actual rules that governed the life of people in Madinah. We will start with an extract from the last sermon that Prophet Muhammad delivered while he was doing pilgrimage in Makka in the tenth year of Hijra. In this sermon, he asserts that all people are equal regardless of ethnicity or color:

There is no superiority for an Arab over a non-Arab and for a non-Arab over an Arab; or for white over the black or for the black over the white except in piety. Verily the noblest among you is he/she who is the most pious. ("Prophet Muhammad's Last Sermon")

According to this sermon, Islam does not accept any type of ethnocentrism that leads to the perception of 'the superior race', who considers others as 'the subject races' or 'people of inferior gods'. The "other" in this sermon is the "non-Arab" whose otherness is a matter of linguistic difference only. As for the "black" and "white," they relate to human beings in general, because Arabs and non-Arabs include both colors. No one is superior over another or others except for the goodness of their deeds and acts. These deeds and acts are an outcome of piety in the context of this extract from the sermon. Piety implies doing what is good for the self and others. This goodness represents practicing the general Quranic rules that call Muslims to accept diversity in the world whether this diversity relates to Arab communities or to non-Arab ones. It is remarkable that Prophet Muhammad does not speak here of "Muslims and "non-Muslims", but of "Arabs" and "non-Arabs," and of "black" and "white," a fact that limits difference language, color and ethnicity and regards piety as a personal and behavioral attribute that can be acquired by any one. Moreover, it relates piety to nobility or vice versa, because both are interrelated and reflect one another.

Islam seeks a real intercultural society where followers of different religions or religious creeds achieve a harmonious co-existence as being human beings first. Here, religion is regarded as a means of piety and nobility, and whatever achieves such goals is regarded as noble and as an act of piety. Historically, this was represented in the tolerance that non-Arabs/non-Muslims enjoyed in Muslim countries in the early phases of Islam. As Karen Armstrong (2002) points out:

In the Islamic empire, Jews, Christians and Zoroastrians enjoyed religious freedom. This reflected the teachings of the Qur'an which is a pluralistic scripture, affirmative of other traditions. Muslims are commanded by God to respect the People of the Book, and reminded that they share the same belief and the same God.

Practically speaking, Prophet Muhammad dealt with so many types of people of different religions, races, ethnicities and he proved himself a good example to be followed by his companions. He advised his followers that differences among mankind are what Allah has meant them to be, and that the existence of Jews and Christians and even non-believers is something that would last forever.

When he went to Madinah, he did not force followers of other religions to convert to Islam. He respected their right to stick to their religions and guaranteed them freedom of worship and 
autonomy in their religious institutions. He left it to them to manage their own affairs as long as they lived in peace and co-existence with others.

The analysis of some of the articles of the Madinah Charter or Constitution will explain a practical example of how Prophet Muhammad turned Quranic principles and rules into practice. Before analyzing the Charter, it is important to understand the context that necessitated it. Before Prophet Muhammad's arrival, Yathrib, later called the Madinah of the Prophet, was a city in which various other faiths were present. There were Jews, polytheists, and others who were not affiliated with any religion. Moreover, the city had been full of tribes who were with obvious ethnic prejudices and who frequently elevated the interests of their tribal members above those of others. It was not very easy for those people to live together in harmony. One group could become hostile towards another over the slightest word or action. As a place of diverse tribes and religions, Yathrib was predisposed to tension and instability. Religious differences led to potential conflict and tribal disputes had been aggravated by social and economic injustices. Long-standing hostilities interfered with the ability of each individual living in Yathrib to see each other clearly, leaving them to view each other according to established stereotypes and prejudices. At that time, Yathrib was in need of a spiritual leader, and they found such a leader in Prophet Muhammad when he immigrated to it. On his arrival, the tribes in Yathrib needed him to act as a third-party negotiator to put an ends to the endemic conflicts between them. He acted as an "arbiter between the rival factions and thus help[ed] to maintain peace in the oasis" (Watt 1956, 96).

Madinah Charter or Constitution is a document addressed by Prophet Muhammad to all the inhabitants of Madinah after his migration from Makka to Madinah. It is a charter that organizes the affairs of life among all the related parties whether Muslims or non-Muslims. It represented a religious, cultural, and political breakthrough at that time because it called for peace and coexistence among all people regardless of their religious, ethnic, or tribal backgrounds.

According to Jose Luis Cordeiro, the Madinah Charter "is said to be one of the earliest constitutions which guarantees basic rights to religions and adherents as well as reinforcing a judiciary process regarding the rules of warfare, tax, and civil disputes" (2009, 18-19). To another, this constitution is "an obvious potential exemplar for those wishing to govern in an Islamic fashion. It also accounts for the possibility of an Islamic pluralism that allows for peaceful religious coexistence within a Muslim state" (Kleidosty 2011, 4).

Prophet Muhammad knew that one of the main reasons of the hostilities among the tribes in Madinah was their disregard and contempt for rights for each other and this resulted in barbarous acts that led to wars and separation rather than peace and unity. After making sure that everyone in Madinah, regardless of his religion, race or ethnicity, was enjoying the freedom of belief, he sought to erase the main cause of people's hostilities. In this way, he managed to establish peace by asking each one to shoulder the responsibility of maintaining it.

The way Prophet Muhammad dictated the phrasing of the constitution, himself being illiterate, is similar in many ways to the methods of writing modern and contemporary constitutions. For example, similar to modern methods of resolving the tensions among conflicting groups, he had espoused some techniques in order to reach a compromise among others of different interests, religions, and ethnicities. "These techniques can be compared to methods present in modern conflict resolution theories, including fractionalization, focusing on interests and goals, and attempting to change the perceptions of power among participants" (Yildirim 2006, 111). Moreover, similar to some modern and contemporary treaties, Prophet Muhammad mentions that the constitution is a pact between all people of Madinah, outlining the main rights and duties of each partner who signed this charter. Right from the very beginning, Prophet Muhammad states the main partners of the constitution in Article 2: under the title of Constitutional Subjects of the State:

(This shall be a pact) between the Muslims of Quraysh, the people of Yathrib (the Citizens of Madinah) and those who shall follow them and become attached to them (politically) and fight along with them (All these communities shall be the constitutional subjects of the state.) (Tahir-ul-Qadri 2000, 116) 
The main associates of the constitution are: Muslims of Quraysh, who migrated to Madinah and the people of Yathrib who are a diversity of different tribes, ethnicities and cultural minorities including: Jews, Muslims and others.

When we look at the way the parties of this charter are mentioned, we find that referring to Muslims is restricted to those who had migrated from Quraysh/Makka because all of them were Muslims. As for the second party, it is referred to as "the people of Madinah" who are made explicit by the translator in a parenthetical note as "the Citizens of Madinah." At that time, many of the people of Madinah had adopted Islam as a religion. Nevertheless, they are mentioned as belonging to the second party involved in this charter. This calls our attention to the political and social nature of the charter; otherwise, it would have included all Muslims within the first party. In addition, the mentioning of future followers of both parties implies that each party could expand itself and make coalitions. Religion was not an exclusive or discriminatory factor in this charter. Article 2 refers only to the religion of one party of the charter because this party was known by this religious epithet at that time. It acknowledged the pluralism that was a social, religious, ethnic, and political fact in Madinah at that time. The charter as a whole was "an example of finding resolve in a dispute where peace and pluralism were achieved not through military successes or ulterior motives but rather through respect, acceptance, and denunciation of war" (White 2014)

A significant number of the articles or sections of the charter address issues that are not related to religion and concern the common aspects of life that pertain to all the inhabitants of Madinah as a one community. This implies a concept of coexistence and peaceful life where all people regardless of their ethnicities, religions, or social backgrounds can participate and serve the interests of one another. In this light, the mental image conveyed or sustained by the charter suggests a view of a plural society that can incorporate all kinds of people and strengthen their mutual understanding, social relations, and acceptance of the concept of the state that covers all without discrimination or segregation.

Articles that deal with the relationship with the other guaranteed religious freedom to the non-Muslim subjects of the Madinah. Prophet Muhammad's way of managing the relations between different religious communities is clearly stated in the Madinah Charter. The Constitution emphasized the fact that people were free in belief and they should live in peace, security and liberty in Madinah as long as they adhered to the Charter. They would enjoy freedom in practicing their religion, and their traditions would be respected. No one should abuse them, put them in danger or attack their lives, properties or places of worship as long as they agreed on the articles of the charter. The obvious example of this religious freedom is evidently stated in Article 30:

The Jews of Banu Awf (non-Muslim minorities) shall be considered a community along with the believers. They shall be guaranteed the right of religious freedom along with the Muslims. The right shall be conferred on their associates as well as themselves except those who are guilty of oppression or the violators of treaties. They will bring evil only on themselves and their family. (Tahir-ul-Qadri 2000, 145)

In this article, Prophet Muhammad proclaims freedom of religion for all peoples and all tribes. Moreover, this article guarantees freedom of religion in terms of adopting and practicing it. It emphasizes individual personal liberty of adopting the religion of one's choice without compulsion. Jews and others have the freedom to observe their respective religions and to practice their faith without fear of, or interference from, others. Freedom of religion in this article implies that nonMuslims are not compelled to convert to Islam, nor are they hindered from practicing their own religious rites. All these rights are derived from the fact that they are human beings with essential rights that cannot be infringed by anyone as long as the articles of the charter that organize the life of all are respected and adhered to. Moreover, the article implies that every religious group is free to take care of its own religious affairs, and to form its holy institutions. The sole purpose of this article was to provide independence and tolerance to the ones who belonged to other religions, beliefs, and races.

Again, this article is more specific on religious matters. The Quran repeatedly emphasized that humans have freewill and they are free to believe as they choose. Islam never accepts 
compulsion, and the enforcement of God's law cannot be properly achieved unless man is free from fear. The non-Muslim is regarded as an "other" in a neutral sense of the term, because otherness implies only non-discriminatory difference as we have shown earlier on in this article when discussing some Quranic verses. In this context, otherness is understood to be difference in religion only. In all other aspects of life, this other becomes part of the collective entity encompassing the community at large. He or she has rights and obligations equal with those of any other members of the community. However, this religious freedom is associated with a sense of responsibility towards the community as a whole. All residents of Madinah, regardless of their religion, should cooperate in resolving economic hardships and defending Madinah in cases of attack by outsiders.

In another article, 50, which says, "a person given constitutional shelter shall be granted an equal right of life protection as long as he/she commits no harm and does not act treacherously. Protection shall be granted to everyone who has been given the Constitutional Shelter" (Tahir-ulQadri 2000, 166). The fundamental rights of the religious other, according to this article, are their protection from all external threats, their protection from internal tyranny and persecution and their right to their own personal law according to the teachings of their own religions. According to this article, the religious other enjoys security and equal rights of life protection and justice. Under this constitution, no distinction of race or religion can ever obliterate the right of a non-Muslim to live in peace. Muslims and non-Muslims should be protected and treated equally. Because of this constitution, "the various autonomous tribes were incorporated in a single confederation with common rights and responsibilities" (Crane 2009, 8). It also "addressed specific social issues of the community in an attempt to end the chaos and conflict that had been plaguing the region for generations" (Yildirim 2006, 110).

Madinah had two main forms of otherness: the other who was of a different religion (Muslims vs. pagans, and Jews), and of a different origin (Madinah Natives vs. Meccan immigrants). In the first form, pagans and Jews were others to Muslims, whereas the second regional or geographical form implies that Meccan Muslim immigrants were others to Madinah Natives. However, this otherness was a matter of difference only, whether this difference was religious or geographical. In all cases, Prophet Muhammad interacted with others by focusing not on the negative aspects of being different, but by finding a point of contact where they could get together away from any differences that might split them away. According to Toss and Diaz (2009, 2-3),

When we develop a clear and objective view of what the other really is, and not what he assumes to be, we will have the chance to get closer to him and consequently, we will allow him to try to forge a certain image of us that is different from the one he had before.

Prophet Muhammad had this clear and objective view of what the other thought. $\mathrm{He}$ possessed the double vision of an insider who was once an alien himself. He was well aware of the controversial position in which his position as a Prophet placed him. Knowing of the psychology of human beings that people tend to define themselves solely by what differentiates them from others, and, thus, conflicts oftentimes arise leading to hatred or distortion of the other, Prophet Muhammad believed that embracing otherness would be one of the things that would elevate the tension between the warring factions in Madinah. In that sense, "an aspiration to a non-violent relationship to the Other," (Cornell 1992, 62) would be the very first step in the long and sometimes painful process of reaching him/her. Prophet Muhammad knew that it does not make a difference whether the other is "primordially good" or not "for prescribing a non-violent relationship with him or her or it" (Hagglund 2004, 40). At this point, this other would no more be the despised other, but a human being who has rights and obligations like any other member of the community.

Moreover, Prophet Muhammad believed that there was no room for any kind of prejudice against the beliefs and practices of the religious "other" because such a prejudice would very often intensify conflicts and tensions among people, and contribute to misunderstanding. Toynbee (1948, 205) associates this with "the extinction of race consciousness" which could spread "tolerance and peace" in the world because this sort of consciousness very often engenders negative attitudes towards other races and ethnicities. 
To sum up, the procedures that Prophet Muhammad had adopted while drafting the Madinah Constitution proved that he was good at dealing with the psychology of the others. Before the Charter became a reality, he talked to the leaders of each tribe, thereby signifying his keenness to listen to the requests of the various religious and political others. The result was that the charter "outlined the rights and duties of its citizens, provided collective protections for all citizens of Medina, including both Muslims and non-Muslims, and provided the first means of seeking justice through law and community instead of tribal military actions" (Yildirim 2006, 111).

\section{Othering in Modern and Contemporary Usage}

One of the problems that lie in dealing with the concept of the other is its complex definitions and the various negative images related to most of these definitions. For example, various thinkers agree that there is no such exact definition of the other simply because the concept is in itself complex and changing. As Sara Rismyhr Engelund (2011) has rightly said,

The concept of "the other" is a complex one, and it is hard to pinpoint exactly what it means. Does it have any meaning at all? The question of who the other is might seem useless, because in some way we are all "others" to someone, and everyone else is "other" to us. We can never fully know the other, and even if we strive to do so, "the other" is constantly changing.

This concept of the other lies in difference only, and it is similar in many respects to the otherness propagated by the Quran and discussed earlier on in this paper. In this sense, otherness is a fact of life; it is natural for peoples, nations, races, etc., to be different from each other.

Although it is truly difficult to provide one exact definition of the other, it is still very useful for the purpose of this paper to survey the various meanings of this concept. For example, according to Chris Weedon, "Othering" refers to the process of "constructing another people or group as radically different to oneself or one's own group, usually on the basis of racist and/or ethnocentric discourses" $(2004,166)$. Construction implies that othering is not natural because it is created by a people or a group in order to distinguish themselves from other peoples or groups so that oneself can be seen as superior to those who are different from them.

In another definition by Joan M. Anderson, Othering has been defined as "an act of representation by which identity is assigned, human existence is categorized, people are characterized according to certain criteria, and experiences are homogenized" (2004, 240). Again, representation and what it portrays relates to the ones who undertake it, because the resultant images of this act of representation does not necessarily give us a true image of the represented. Coupland correlates this act of representation with the purpose of distancing and alienation who are represented through othering. For him, 'Othering' refers to "the process of representing an individual or a social group to render them distant, alien or deviant" $(1999,5)$. In this context, othering is an act of categorization that distances who is different from the self and quarantines $\mathrm{him} /$ her away from the self so that it can be seen in a negative light and regarded as an inferior who cannot attain the advantageous position of the self. It is a way of representation that cannot be, in most cases, true to the represented because it reflects the misconceptions, preconceptions, and biased projections of the one who undertakes this act of representation.

Throughout history, each society and culture tend to have their "others," and set a group of images for these others. These images are the construction of history and of a culture that perpetuates them. As Engelund (2011) puts it, "it's hard to imagine a society in which we divide people into "us" and "them" without putting "us" above "them." In many cases, this other has been represented in more negative images than positive ones. For example, in some societies, the other is perceived as "physically and intellectually inferior, morally suspect, heathen, licentious, diseaseridden, feral, violent, uncivilized, infantile, and in the need of the guidance of white, Anglo-Saxon Protestants" (Marchetti 1993, 2-3). In addition to these negative images of the other, one can add to the list how the other is perceived as different, weak, evil, subordinate, enemy, hostile, and must be colonized. According to Richard Kearney $(2003,65)$,

Otherness was considered in terms of an estrangement which contaminates the pure unity of the soul...the other is an adversary, the stranger a scapegoat, the dissenter a devil. It is this 
proclivity to demonize alterity as a menace to our collective identity which so easily issues in hysterical stories about invading enemies.

In this light, the concept of otherness creates a dividing line that "estranges" who is not the self and confines them to a position in contrast with which the self occupies a positive and advantageous status that can give a good definition of this self and displace the other into an evil definition. Hence, the other is reduced to an abstract entity that has no real existence except as a mental construct in the minds of the ones who have created and categorized it in this way.

In modern times, especially in colonial and post-colonial cultures, the other is always perceived negatively. In colonial societies, the Other used to be perceived as being different in some fundamental way. This Other is nothing more than a "foreigner" or an "outsider." It generally "includes those outside of, and implicitly subordinate to, the dominant group" (Joffe 1999, 18). Being "outside" is understood as meaning "alien," "wild," faraway from culture and civilization. This segregational understanding is used to justify cultural subordination and even sometimes military subjugation of what/who has been earlier classified as the other. Moreover, this other is seen as different because he/she has different sets of behavior or ways of living, language, race, color and religion that are perceived by the self as completely different and consequently need containment and cultural quarantining. These differences exist within each community as well as across cultural boundaries, as we have highlighted earlier on in this paper when discussing the Quranic verses that emphasize difference as part of the design of God. It is natural for human societies to be different from one another and to have their distinctive cultural features that may or may not partially converge with those of other societies. However, as Melamed puts it: "the other is then not only qualitatively different, but the complete opposite of himself, and hence naturally inferior. Someone who is the exact opposite of the beautiful and the good will, of logical necessity, be ugly and evil" $(2003,26)$. In other words, cultural difference is used as a means of demonizing who is different with regard to the self and treating him/her as not having any common trait or feature with the self. This turns the other into a feared entity that should be "treated" in the medical sense of the verb in order to be similar to the self not represent any sort of danger to this self. Moreover, the other is regarded in some communities as filth and therefore, it must be banished and destroyed. According to Miroslav Volf $(1996,27)$,

Otherness is filth that must be washed away from the ethnic body, pollution that threatens the ecology of the ethnic space. The others will be rounded up in concentration camps, killed and shoved into mass graves, or driven out; monuments of their cultural and religious identity will be destroyed, inscriptions of their collective memories erased; the places of their habitation will be plundered and then burned and bulldozed.

This image of the other has ideological bases whether this ideology is religious or not. It depends on a "pure" image of the self which is endangered by the "filth" that is substantiated by the other. In order to keep the "purity" of the self, all the manifestations of "impurity" must be obliterated or at least "purified."

From another perspective, Othering is a process where a dominant group looks at the other as a subordinate or has no subjectivity. This view of the other does not regard him/her as a self that is not different from one's own self except in the manifestations of this selfhood. It objectifies the other and deprives him/her from any subjectivity or selfhood. Objectification suggests that the other is reduced to a mere commodity which has instrumental and use value only. It "is viewed as a mere commodity which can be consumed at any time without any moral scruples" (Elgezeery 2014, 10). Its "otherness is manipulated in portraying the self as playing a civilizing role" (Elgezeery 2013, 34) that can justify subjugation and occupation of the other and "its" lands. That is why other accompanied colonialism.

In the eyes of the colonizers, the other is always barbarous and uncivilized and therefore, must be colonized apparently in order to civilize him/her. This colonial attitude widens the scope of the other so that it can cover whole nations, countries, or cultures. In this context, othering implies an act of representation that categorizes and stereotypes whole groups as inferiors who are in need of the civilizing mission that can be affected through colonization and subjugation. This 
colonializing attitude has been the most universal way for one group to rule the other who is always singled out for unequal treatment and is considered as an object of prejudice and discrimination. According to Engelund (2011),

When we "other" another group, we point out their perceived weaknesses to make ourselves look stronger or better. It implies a hierarchy, and it serves to keep power where it already lies. Colonialism is one such example of the powers of Othering.

Hierarchization or pyramidal ranking places the self at the top of the hierarchal order. The purpose of this position is to privilege the culturally, socially, politically, and economically and justify the unequal treatment of what/who has been downgraded into an inferior other.

In the $19^{\text {th }}$ and early $20^{\text {th }}$ centuries, in order to advocate for their cause, colonizers claimed that the other is the Enemy, and hence, it must be excluded, destroyed and killed. The Enemy appears when "We/Us" and "They/Them" are thought to be fundamentally different, emerging from the Other in times of war and other societal violence (Wingfield 2003, 1). According to the advocates of colonialism, the other becomes an enemy when it becomes different and threatening to the self. It is perceived as aggressive and evil in its nature. As Vilho Harle puts it: "The Enemy is a special case of the Other; the Enemy represents Evil (the Devil), while the Self represents Good (God). The relationship between the Enemy and the Self, therefore, adds hostility and violence to the identity-creating relationship" $(2000,15)$. This Other is perceived usually as an 'enemy' in a battle of good versus evil, 'us against them'. Colonizers use this manifest demonization to justify occupation and spreading their own culture, including their religion, as representing the "cure" that will rid the colonized of what ails them.

This act of othering suggests a misconception of difference. As we have argued earlier on in this paper, difference is the norm, not the exception. It is part of human nature and life that peoples and nations are different from each other, and within each people or nation, individuals are different. The concept of individuality itself indicates that every individual human being is not expected to be identical with another. Knowing that differences are the normal will allow us to see that "the other is not myself - and who has ever maintained that it is? but it is an Ego" (Derrida 1978, 10). Iver Neumann $(1999,17)$ elaborates this point. He writes:

Indeed, if there were only two of us in the world, I and one other, there would be no problem. The other would be completely my responsibility. But in the real world there are many others. When others enter, each of them external to myself, problems arise. Who is closest to me? Who is the Other? Perhaps something has already occurred between them. We must investigate carefully. Legal justice is required. There is need for a state.

Modern and contemporary thinkers and philosophers suggest that we must first perceive the other through their own eyes, not through our own particular lens. In that way, the other will not be the enemy, but a potential friend.

\section{Contemporary Muslims and Othering}

Having surveyed the concept of the other is the early phase of Islam, whether through analyzing some Quranic verses or shedding light on some of the practices of Prophet Muhammad, and then tackled the radical changes of this concept in contemporary theory and practice, the paper will deal with the concepts of the other in contemporary Muslim societies. We use "concepts" in its plural form with reference to contemporary Muslims because they are not a homogenous or unified group in the present. Muslims now are many groups, nations, sects, and communities. Even within the same sect, say Sunnis or Shiites, there are different views of the other.

First, we have to distinguish between some terms related to contemporary Muslims. The word "Muslim" itself can be used in two senses: a motivated sense which is correlated with Islamism or Jihadism in their religiously disguised political senses, and a neutral sense which relates to the religion of large populations of some countries. The first sense is what is meant when speaking about the negative implications of Othering in contemporary Islam. It covers those who adopt Islamism or Jihadism as a political ideology and some people whose minds are "colonized" 
by this ideology. The second sense covers those who adopt Islam as a religion and regard religion as a means that positively supports and furthers life.

This terminological distinction leads us to another distinction which is that between liberal Muslims and conservative Muslims. In this context, liberality and conservatism largely relate to the interpretation of basic Islamic religious texts, namely, the Quran and authenticated Hadiths of Prophet Muhammad. Liberals interpret these texts in the light of the overall goals and objectives of Islam as a religion that can adapt itself to the historical and temporal changes of human life on earth. The conservatives interpret these texts literally and exclusively. Literal interpretations take the surfaces of these texts as having categorical meanings, and they are influenced by later interpretations that were implicated in political struggles and subsumed the religious under ideological interests of the interpreters. Sayyed Qutub's interpretation of the Quran can be taken as an example of such assumption. In this context, the wide and inclusive concepts and ideas, which are exposed in the Quran and Hadiths and relate to humanity at large, were narrowed so as to exclude all non-Muslims and even some Muslims who are regarded by the interpreter as straying from the right path.

The third distinction is between the political regimes in largely Muslim countries. Most of these political regimes adopt a tolerant view of Islam and are largely liberal in this context. Only few regimes, such as in Sudan and Somalia, adopt an exclusive, reductive, and narrowed view of Islam that is largely used to justify their suppressive and oppressive political practices in the eyes of their peoples and to exploit the rigid and extremist worldviews of some of their "citizens" in the legitimation of their political power. In this context, othering is exterior, as it is used against other Muslim and non-Muslim states and political regimes. Even liberal Muslim regimes can sometimes resort to this extremism in order to create an unstable domestic position that is used to inculcate in the minds of the citizens that the continuity of the regime is a guarantee against chaos and the rarity of basic goods. In this context, othering is domestic because it relates to the fractionalization of those who criticize or oppose these regimes: this fractionalization may be political, religious, ethnic, etc. The regime portrays the criticizing or opposing groups as endangering the unity and "independence" of the country.

The age of colonialism has had negative impacts upon the countries with large Muslim implications. In addition to political and economic exploitation, some Muslims regard the age of colonialism as a new disguised wave of the "crusades" in which the West, which is largely Christian, has waged a new form of war against Muslims just because they are Muslims. However, this reasoning is largely fallacious because the colonial West did not differentiate between Muslims and non-Muslims: many non-Muslim countries were subjected to colonialism, and Muslim countries do not consist of exclusively Muslim populations. For example, Egypt has Muslim, Christian, Jew, and non-believing populations and it suffered from French and British colonialism.

The Crusades played a decisive role in changing Muslim view of the religious other. The Quranic view of the religious other incorporates it within the law or norm of difference that governs human life on earth. This difference, as we have shown above, has nothing to do with superiority or inferiority: God has diversified human beings into different nations, tribes, and colors so that they can get into contact with each other and come to know each other better; only good deeds and acts can make someone better than others. In this light, Christians, who are the subject of the Crusades, were regarded as having equal rights to everything. However, when Muslims saw that Christians waged the Crusades for religious reasons and made Muslims inferior and even pagan others, they started to review their view of the religious other and reinterpret Quranic verses so that their interpretation can accommodate an updated view of the other that could be truthful to reality. There are other Quranic verses that urge Muslim to respect anyone who does not attack them and state that "God does not love attackers/transgressors." The Christians waging the Crusades were seen as belonging to those attackers, and therefore they were moved out of the neutral or positive concept of the other that was based on positive difference and incorporated into the transgressing other who could not be treated as equal or as deserving respect or tolerance. 
Colonialism has had a negative impact in another respect. As we have indicated earlier in this paper, colonialism was based on othering in the negative sense of the term. It represented the countries that would be occupied as inferior and barbarous in order to use its civilizing role as a justification for colonializing these countries. This view of the other has had its ideological and formative effects upon the Muslim concept of the other as relating only to positive difference, as we have shown when we discussed the Quranic view of the other earlier in this paper. As colonial powers have regarded Muslim countries as inferior others, some Muslims began to adopt this view of the other as inferior and used it against western colonial powers themselves. Later on, this view was extended to cover all western people through some kind of overgeneralization. The west as a whole came to mean the colonizer, the enemy, the barbarous, the unbelievers, the deviant from the right path, etc.

All these kinds of Othering affected by colonialism relate to exterior otherness, i.e. that which relates to western powers and the west in general. However, there is another kind of domestic othering where colonialism also played a role. It was a result of the colonial policy of "Divide and Conquer." The fractionalization resulting from this policy divides the same community or country into separate groups that usually regards each other as radically different. This leads to the creation of many others within the same country. Each of these others regards itself as distinct and superior, endangering the unity of the country itself. In this sense, othering can be religious (Muslims vs. Christians, Sunnis vs. Shiites, Wahhabis vs. Hannafis, etc.), tribal (Kurds vs. Arabs, Bedouins vs. urbans, Nubians vs. Egyptians, etc.), or even political (left wing vs. right wing, secularists vs. nationalists). For example, after US invasion of Iraq in the 1990s, Iraq, which was largely seen as a unified nation, came to witness tribal and religious sectarianism that has been perturbing the country since then.

As for Islamic history itself, Muslims came to regard one another or each other as "others" early in Muslim history. Three of the Guided Caliphs, who consecutively reigned the Muslim nation after Prophet Muhammad's death, were killed. Two of them were killed in political struggles among Muslims. Politics was used, early in the history of Islam, as a means of twisting the meanings and interpretations of religious texts so that the politically different can be incorporated into an ideologically colored image of an inferior other. In other words, Muslims became divided into sects that were originally political.as Islam itself called for the unity of all Muslims at that time, all these sects were to be seen by neutral observers as deviating from the path of Islam. In order for each sect to portray or represent itself as sticking to the right path, it began to represent the other sects as deviating from the right path. This was the first act of "othering" in the negative sense of the term in Islam and led, later on, to many forms of othering with the ramification of sectarianism in Muslim societies. As long as Muslims "othered" each other, it was not strange for them to "other" the followers of other religions. In our view, this was the first instance of political Islam in Muslim history. It leads us to distinguish between Islam as a religion which has a positive view of difference and otherness, and political, extremist, or even social Islam which relates to Islam as a religion only apparently because it is exploited to serve ends that are not consistent with Islam as a tolerant and inclusive religion. For example, women are "othered" in some Muslim countries as inferior and consequently are sometimes reduced to the status of slaves or servants; those who "other" them erroneously interpret some unauthenticated religious texts that belong to later stages of Muslim history and attribute these false interpretations to Islam itself.

\section{CONCLUSION}

In conclusion, during the time of Prophet Muhammad in Madinah, the Concept of the other is strictly similar to the one described in the Holy Quranic verses. The Prophet himself provides an exemplary practice of the Islamic view of the Other in writing a constitution for people of different religions, tribes, races and ethnicities, living in Madinah. Those others who had agreed to that constitution were allowed to worship in their own way and follow their own family law, and were given a degree of self-government. However, After Prophet Muhammad's death in 632, Muslims' conceptions of the other greatly changed partly because of political reasons and conflicts among 
themselves and in most cases, because of the western colonization of many Muslim countries. In Modern and contemporary time, European and western countries colonized many Muslim countries and tried to destroy their cultures and religion. As colonial powers have regarded Muslim countries as inferior others, some Muslims, as a reaction to this colonial attitude, began to stray away from the original concept of the other as practiced by Prophet Muhammad, and adopt this view of the other as inferior and used it against western colonial powers themselves. Later on, this view was extended to cover all western people through some kind of overgeneralization. The west as a whole came to mean the colonizer, the enemy, the barbarous, the unbelievers, the deviant from the right path, etc. Even after their independence, many Muslim countries have been largely ruled by military and despotic governments. Following the same colonial doctrine of "Divide and Rule, those dictatorial governments seek to create an unstable domestic position to inculcate in the minds of the citizens that the continuity of the regime is a guarantee against chaos and the rarity of basic goods. In this context, othering is domestic because it relates to the fractionalization of those who criticize or oppose these regimes: this fractionalization may be political, religious, ethnic, etc. The regime portrays the criticizing or opposing groups as endangering the unity and "independence" of the country.

\section{References}

[1] Anderson, J.M. 2004. "Lessons from a Postcolonial-Feminist Perspective: Suffering and a Path to Healing." Nursing Inquiry, 11(4): 238-246.

[2] Armstrong, Karen. 2002. "The Curse of the Infidel." The Guardian, June 20. $\mathrm{http}: / /$ www.guardian.co.uk/world/2002/jun/20/religion.september11 (Accessed on September 12, 2014)

[3] Can, Sefik. 2005. Fundamentals of Rumi's Thought. Ed. and Trans. Zeki Saritoprak. New Jersey: The Light, Inc.

[4] Cordeiro, Jose Luis. 2009. Constitutions around the World: A View from Latin America Germany: Lap-Lambert Academic Publishing.

[5] Cornell, Drucilla. 1992. The Philosophy of the Limit. New York: Routledge.

[6] Coupland, Nikolas. 1999. “Other Representation.” In Handbook of pragmatics, edited by Jef Verschueren et al., 1-24. Amsterdam \& Philadelphia: John Benjamins.

[7] Crane, Robert D. 2009. "Islamic Social Principle of the Right to Freedom (Haqq alHurriyah): An Analytical Approach." Arches Quarterly, 3 (4): 5-14.

[8] Derrida, Jacques. 1978. Writing and Difference. Trans. Alan Bass. Chicago: University of Chicago Press.

[9] Elgezeery, Gamal. 2013. "Cross-Referencing Nature and Culture in Nol Alembong's Forest Echoes." International Journal of English and Literature, 3 (2): 27-40.

[10] Elgezeery, Gamal. 2014. Human Objectification in Carol Ann Duffy's The World's Wife. Saarbrucken, Germany: Lap Lambert Academic Publishing.

[11] Engelund, Sara Rismyhr. 2011. "Introductory essay: 'The other' and 'Othering," New Narratives: Multicultural Literature at the University of Oslo, issue 2, http://newnarratives.wordpress.com/issue-2-the-other/other-and-othering-2/ (Accessed on 10 September 2014))

[12] Hagglund, Martin. 2004. "The Necessity of Discrimination: Disjoining Derrida and Lévinas" Diacritics: A review of Contemporary Criticism. 34 (1): 40-71.

[13] Harle, Vilho. 2000. The Enemy with a Thousand Faces: The Tradition of the Other in Western Political Thought and History. Westport, CT: Praeger Publishers. 
[14] Joffe, Hélène. 1999. Risk and 'The Other'. Cambridge: Cambridge University Press,

[15] Kearney, Richard. 2003. Strangers, Gods and Monsters Interpreting Otherness. London: Routledge.

[16] Kleidosty, Jeremy. 2011. "From Madinah to Runnymede: Comparing the Foundational Legacies of the Constitution of Madinah And The Magna Carta." New Middle Eastern Studies, 1: 1-14. http://www.brismes.ac.uk/nmes/wpcontent/uploads/2011/11/NMES2011Kleidosty.pdf (accessed September 11, 2014).

[17] Marchetti, Gina. 1993. Romance and the Yellow Peril. Berkeley: University of California Press.

[18] Melamed, Abraham. 2003. The Image of the Black in Jewish Culture: A History of the Other. Trans. Betty Sigler Rozen. New York: RoutledgeCurzon.

[19] Neumann, Iver B. 1999. Uses of the Other: "The East" in European Identity Formation. Minneapolis: University of Minnesota Press.

[20] Prophet Muhammad's Last Sermon (http://www.stanford.edu/ jamila/Sermon.html)

[21] Quran. Bilingual Edition: Arabic-English. Trans. Muhammad Asad.

[22] Tahir-ul-Qadri, Dr. Muhammad. 2000. Constitutional Analysis of the Constitution of Madinah. Minhaj-ul-Quran Publications.

[23] Toss, Liliane, and Salomon Diaz. 2012. "Embracing the Arab Speaking Community in the Cultural Diversity of the American Society." http://forest.huntington.edu/cccda/files/2009/05/toss-the-arab-speaking-revised.pdf (Accessed on December 20, 2012).

[24] Toynbee, Arnold J.1948. Civilization on Trial. Oxford: Oxford University Press.

[25] Volf, Miroslav. 1996. Exclusion and Embrace: A Theological Exploration of Identity, Otherness, and Reconciliation. Nashville: Abingdon Press.

[26] Waardenburg, Jacques. 1999. Muslim Perceptions of Other Religions: A Historical Survey. New York and Oxford: Oxford University Press.

[27] Watt, W. Montgomery. 1956. Muhammad at Medina. Oxford: Clarendon Press.

[28] Wingfield, Nancy M. 2003. Creating the Other: Ethnic Conflict and Nationalism in Habsburg Central Europe. New York: Berghahn Books.

[29] White, Sean William. 2014. "Medina Charter of Prophet Muhammad and Pluralism." January 23. http://www.islamicity.com/Articles/articles.asp?ref=IC1102-4508 (accessed 9 September 2014).

[30] Weedon, Chris. 2004. Identity and Culture: Narratives of Difference and Belonging. Berkshire, UK: Open University Press.

[31] Yildirim, Yetkin. 2006. "Peace and Conflict Resolution in the Medina Charter," Peace Review: A Journal of Social Justice. 18 (1): 109-17. 